\title{
When Do the Dispossessed Protest? Informal Leadership and Mobilization in Syrian Refugee Camps
}

\author{
Killian Clarke
}

\begin{abstract}
Refugees are often considered to be among the world's most powerless groups; they face significant structural barriers to political mobilization, often including extreme poverty and exposure to repression. Yet despite these odds refugee groups do occasionally mobilize to demand better services and greater rights. In this paper I examine varying levels of mobilization among Syrian refugees living in camps and informal settlements in Turkey, Lebanon, and Jordan in order to explain how marginalized and dispossessed groups manage to develop autonomous political strength. I explain the surprisingly high levels of mobilization in Jordan's Za'atari Camp compared to the relative quiescence of refugees in Turkish camps and Lebanese informal settlements as the product of a set of strong informal leadership networks. These networks emerged due to two unique facets of the refugee management regime in Jordan: the concentration of refugees in the camp, and a fragmented governance system. In Turkey and Lebanon, where these two conditions were absent, refugees did not develop the strong leadership networks necessary to support mobilization. I develop this argument through structured comparison of three cases and within-case process tracing, using primary source documents from humanitarian agencies, contentious event data, and 87 original interviews conducted in the summer of 2015.
\end{abstract}

$\Lambda$ t 5:30 p.m. on April 5, 2014, the Jordanian police detained several Syrian refugees in Districts 7 and 8 of the sprawling city-cum-refugee-camp known as Za'atari. The detained refugees were being smuggled out of the camp, and upon hearing of the arrests their relatives made calls throughout the nearby districts asking neighbors to intervene to defend their "honor." According to the minutes of the Camp Management Coordination (CMC) meeting, which was held three days later, the events escalated rapidly:
Crowds quickly increased from tens to hundreds to a PSD [police] estimate of several thousand. Police posts in one part of the camp were then attacked with stones \& risked being overrun. Reinforcements were called in from the Badia (Desert Force) who were also attacked. Tear gas \& warning shots using live rounds were fired. Refugees proceeded to burn multiple tents (less than 10) and 6 caravans. Gas cylinders were then thrown into the fires. Other gas cylinders were turned on and the gas ignited and turned towards the security forces. During the clash refugees were shot, with one 17-18 year old male dying early Sunday morning. ${ }^{2}$

A list of permanent links to Supplementary Materials provided by the author precedes the References section.

Qualitative data analyzed in this article have been deposited in the Qualitative Data Repository and can be found at: Clarke, Killian B. (2018) Data for "When Do the Dispossessed Protest? Informal Leadership and Mobilization in Syrian Refugee Camps." Data Project, QDR:10088. Syracuse, NY: Qualitative Data Repository [distributor]. https://doi.org/10.5064/F6CN723S

Killian Clarke is a Doctoral Candidate in the Department of Politics at Princeton University (kbclarke@princeton.edu). His research examines contentious politics, protest, revolutions, and regime change, with a regional focus on the Middle East. He would like to thank Lamis Abdelaaty, Mark Beissinger, Sabri Ciftci, Sarah El-Kazaz, Nathan Grubman, Amaney Jamal, Avital Livny, Kevin Mazur, Rory Truex, Deborah Yashar, as well as participants in Princeton's Comparative Politics Research Seminar and Workshop on Arab Political Development and in the Project on Middle East Political Science's 2015 Workshop "New Political Science Research on Syria's War," and 2017 Workshop "Refugees and Migration Movements in the Middle East" for comments and suggestions on previous drafts. He also thanks Hassan Alassaad, Bulent Aliriza, M. Murat Erdoğan, Gözde Güran, Olimar Maisonet-Guzman, Miraj Pradhan, Nihal Seyfettinoğlu, and Daniel Tavana for assistance and advice with the fieldwork and data collection. Finally, he thanks the Mamdouba S. Bobst Center for Peace and Justice and the American University of Beirut for their generous funding of the research. 
On the day after the event the humanitarian agencies and NGOs in charge of the camp remained safely in their base camp, too nervous to enter the districts where the riot had occurred. Eventually the camp's police ventured in, and went immediately to the caravans of the districts' six "street leaders" - informal authority figures with significant sway within the refugee communities. The street leaders made several demands - for better medical services in the district and replacements of dilapidated caravanswhich the police promised to address, and the meeting concluded with the street leaders pledging to restore calm and guarantee the safety of the NGOs. Within 24 hours NGO staff had resumed their work in the districts. ${ }^{3}$

Although distinctive for its size and violent denouement, the event described here is representative of the type of refugee contention that became commonplace in the Za'atari camp after its opening in the summer of 2012. According to security reports from the United Nations High Commission for Refugees (UNHCR), in 2013 and 2014 the Syrians in Za'atari launched 327 contentious events, including protests, sit-ins, demonstrations, roadblocks, and stone-throwing incidents. ${ }^{4}$ In contrast to typical portrayals of refugees as disempowered subjects, the Za'atari refugees became a highly mobilized community with complex informal leadership structures and a tendency to make claims through the language of contentious politics. Yet, strikingly, in the nearby states of Lebanon and Turkey, which also hosted large numbers of Syrian exiles, patterns of mobilization conformed far more closely to the classic stereotypes. In these sites refugees living in camps demonstrated little of the tenacity and strength that characterized Za'atari's refugee communities, and refugee protests were exceedingly rare.

What explains the divergent levels of mobilization between the Syrian refugees living in Za'atari and those who settled in camps in nearby Turkey and Lebanon? How do refugees, who may be among the world's most marginalized groups, manage on occasion to overcome tremendous barriers to mobilization? I argue that levels of mobilization among refugees and other marginalized groups depend on the strength of their informal leadership networks, which in turn are shaped by the types of regimes that manage and govern them. Specifically, the regime overseeing the Za'atari Camp was marked by a particular configuration of space and governance, which facilitated the emergence of both powerful and autonomous refugee leaders. The refugees in Za'atari were concentrated in one place under the governance of myriad poorly integrated and uncoordinated authorities. This combination of concentration in space and fragmented governance allowed refugees to construct strong informal leadership networks, which then facilitated high levels of mobilization through 2013 and 2014. This unique configuration was absent in both Turkey and Lebanon. As a result, neither in Lebanon nor in Turkey were refugees able to consistently mobilize to make collective demands.
The argument has important implications for academics and practitioners with an interest in refugees, migration, and humanitarianism. If history is a guide, the millions of Syrians living in exile, along with the rest of the world's refugees, will likely remain in their host countries for a considerable time, forcing them to construct new lives and rebuild their communities. Yet we know relatively little about how refugee communities reconstitute themselves in exile and begin to organize politically. Though scholars care about the integration of these groups into host societies, as well as their impact on an array of political outcomes like electoral politics, national identities, redistribution, and violent conflict, little attention has been given to how they overcome structural barriers to mobilization. Moreover, the puzzle of refugee mobilization is in many ways analogous to a broader scholarly question: how do poor and marginalized groups manage to mobilize, protest, and resist authorities, despite tremendous odds? Though this study deals only with cases of refugee mobilization, its findings may have important implications for understanding mobilization processes among a broad array of similarly disempowered and dispossessed groups.

\section{Existing Literature: Refugees and Other Marginalized Groups}

Social scientists have long puzzled over how marginalized social groups, with few resources and little political influence, manage to develop autonomy and strengthin some cases sufficient to resist and combat the powerful actions of states and other authorities. Joel Migdal's classic "state in society" formulation posited that the state, rather than exerting hegemonic social control over the territory it purports to govern, often comes into conflict with powerful social forces capable of resisting its encroachments. ${ }^{5}$ Similarly, work on peasant rebellions was often motivated by the paradox that peasants would seem to be unlikely revolutionary actors given their poverty and societal marginalization. ${ }^{6}$ Social movements scholars puzzled over how poor and homeless people managed to build social movements, defying theories that predicted movement emergence only among well-resourced groups. ${ }^{7}$ And, more recently, studies of the urban poor have asked why communities in certain slums develop the capabilities to effectively lobby governments and gain access to social services. ${ }^{8}$ In different ways, these currents of research all consider the question of how groups on the margins of society develop the strength necessary to resist and engage powerful authorities.

The question of how autonomous social strength may emerge has less commonly been posed about refugees. Political science scholarship on refugees has typically examined the security implications of refugee flows, particularly its connection to violent conflict. These studies have found that large influxes of refugees can be 
triggers for war and ethnic conflict ${ }^{9}$ and that refugees often get militarized and recruited into civil wars. ${ }^{10}$ But in many of these studies the agency of refugees themselves is curiously absent; violence is triggered automatically by refugee "flows" or refugees are manipulated into violence by more powerful armed groups. Moreover, despite the fact that most refugee/host interactions are nonviolent, ${ }^{11}$ there is little consideration of the more prosaic political strategies that refugees use to pursue their goals, or the related question of how they develop political autonomy or engage relevant authorities. This is surprising because political science research has consistently found when considering the broader category of immigrants that new entrants to societies can develop into powerful political constituencies, with the capacity to protest and riot, ${ }^{12}$ influence party nominations and electoral outcomes, ${ }^{13}$ and restructure public goods provision. ${ }^{14}$

Indeed, in research from other disciplines there is plenty of evidence suggesting that refugee mobilization is a recurring phenomenon with important political implications. For example, a host of ethnographic and journalistic accounts of specific refugee camps, particularly in the Middle East and East Africa, have found refugee communities to be surprisingly tenacious and vibrant, with considerable capacity to resist authorities and make demands, including through protest. ${ }^{15}$ While these studies offer rich and vivid evidence regarding dynamics of refugee mobilization, because the scholarship is almost all based on single cases it is difficult to identify which factors are more important than others, and which may have been present in cases where refugee strength was weaker. This is where an explicitly comparative approach can be constructive. By comparing a refugee camp where refugee mobilization was high with two cases in which camp-based refugees were relatively quiescent, I am able to assess which factors most consistently generate this important outcome.

\section{A Theory of Mobilization among the Dispossessed}

Following Charles Tilly's classic definition, I understand mobilization as "the process by which a group goes from being a passive collection of individuals to an active participant in public life." 16 When pursued through non-institutional channels, mobilization often takes the form of contentious claims-making, like protests, boycotts, or strikes. ${ }^{17}$ In the cases that follow I therefore operationalize this variable by studying variation in the making of contentious claims against authorities using both peaceful and violent (though unarmed) repertoires. ${ }^{18}$

The strength of informal leadership networks is, I argue, what explains the variation in this outcome. By leadership network I mean a series of social relationships between individuals with status, authority, and influence within a community. The network is informal when these relationships exist outside the boundaries of formal institutions. The strength of such a network is a product of two factors: the autonomy with which the leaders may act and the density of the ties between them.

Informal leadership networks matter because they allow disempowered groups to overcome two of the most significant barriers to their mobilization: lack of resources and political vulnerability. Social movements scholars often emphasize that access to resources greatly facilitates protest because it allows groups to recruit followers, provide incentives, and build the organizations necessary to sustain mobilization. ${ }^{19}$ And a lack of political influence may leave groups vulnerable to repression, arrest, and cooptation by powerful authorities. Strong informal leadership networks help to overcome both these barriers through two primary mechanisms. First, in the absence of resources to provide incentives, leaders may use other means, like social status or informal influence, to motivate their followers into collective action. Moreover, in a scarce resource environment informal leaders may be the only ones with any resources to speak of-food, cash, goods, etc.- -and they may therefore be able to leverage resource scarcity to their advantage, by providing even stronger incentives for mobilization than would be possible in a scenario of greater resource abundance. Second, where leaders are bound together in networks of strong ties and relationships, they may collaborate to defend each other and their constituencies when they come under threatfor example, by shielding their members from arrest or rallying followers to physically resist encroachments from authorities.

The logic behind this explanation draws, in part, from theories of collective action developed by those proposing solutions to Mancur Olson's famous "free rider problem." ${ }^{20}$ Under these theories groups with greater and denser network ties, i.e., in which more people are connected to each other through direct or indirect social relationships, will be better able to act in unison to achieve a shared goal. ${ }^{21}$ Roger Gould has particularly emphasized that for poor or marginalized groups, informal networksbased in neighborhoods, workplace groups, or friendship circles - may provide the means to solve the assurance problem inherent to collective action. ${ }^{22}$ Other scholars have argued that more centralized networks, in which leaders stand at the intersection of a web of network relations, will better facilitate mobilization, as these leaders will be well-positioned to motivate followers and sanction dissenters. ${ }^{23}$

But this argument simply pushes the question back one step. If strong leadership networks matter for mobilizing marginalized communities, the question then becomes: what produces strong versus weak networks? I argue that two features of the refugee management regimes that Syrians came to live under shaped the character of these informal networks: the degree of 
consolidation of their governance structures and the settlement patterns they promoted. Specifically, where refugees were managed by a fragmented governance regime and concentrated together in one place, they formed strong informal networks and staged recurring protests.

The first variable-fragmented governance-refers to a governance regime characterized by poor coordination, a lack of formal accountability structures, and no central point of authority. Typically, fragmented governance is a phenomenon that has been identified in studies of state formation, ${ }^{24}$ but an analogous phenomenon may also emerge in the governance regimes that manage refugee crises. ${ }^{25}$ In such situations multiple players, with varying mandates, resources, and capacities, must collaborate to conduct many of the activities normally associated with state administration - like providing services, monitoring social life, and enforcing rules. Because of this fragmentation in accountability and coordination they will conduct these activities sporadically or ineffectively; most importantly, they will be unable to effectively police activities or sanction those who violate the rules, giving leaders the space to act without constraint or punishment. ${ }^{26}$ The second variable - spatial concentration — entails the physical colocation of large numbers of people into a relatively confined space, like a refugee camp. This concentration of people into a small, contained space provides the context for repeated face-to-face physical interactions between diverse types of residents and leaders, who come to form multiple relationships and hierarchies. ${ }^{27}$

The theory is schematically laid out in the process map in figure 1 . The two independent variables, fragmented governance and spatial concentration, together lead to the emergence of strong informal leadership networks by removing coercive constraints on leaders' actions (M1) and facilitating the formation of dense network ties (M2). Mobilization occurs when these strong informal leaders motivate their followers (M3) and collaborate with each other to protect against threats from camp authorities (M4). Note that in this argument it is the combination of fragmented governance and spatial concentration that produces the types of networks that facilitate mobilization. Indeed, the presence of one condition without the other may have quite the opposite effect. For example, studies of concentration camps and other "total institutions" have found that a concentrated space governed by a powerful authority may create the conditions for extreme levels social control- a finding that the Turkey case in this study largely confirms. ${ }^{28}$

To test this theory I rely on two well-established qualitative research techniques: the comparative method and within-case process tracing. ${ }^{29}$ I compare three cases, Jordan, Turkey, and Lebanon, with broadly similar characteristics but in which the key dependent variable -refugee mobilization-took on different values. I further control for potential confounding factors by focusing only on refugees located in camps or camp-like settings, where refugee living conditions and social backgrounds were similar across cases. ${ }^{30}$ In Jordan, I focus on the Za'atari camp, which was the only Syrian refugee camp among the cases with strong levels of refugee mobilization. In Turkey I study the 25 formal camps established by the Turkish government, and in Lebanon I analyze the country's myriad informal tented settlements. Because the outcome of interest is uniform across the camps in both Turkey and Lebanon, I often discuss these camps in aggregate rather than focusing on any particular one. I complement the comparative case analysis with process tracing within all three cases to illuminate the mechanisms connecting the variables in the theory and to evaluate alternative theories. To draw my inferences I triangulate across three types of data: 87 interviews conducted during

\section{Figure 1}

\section{Process map of refugee mobilization}

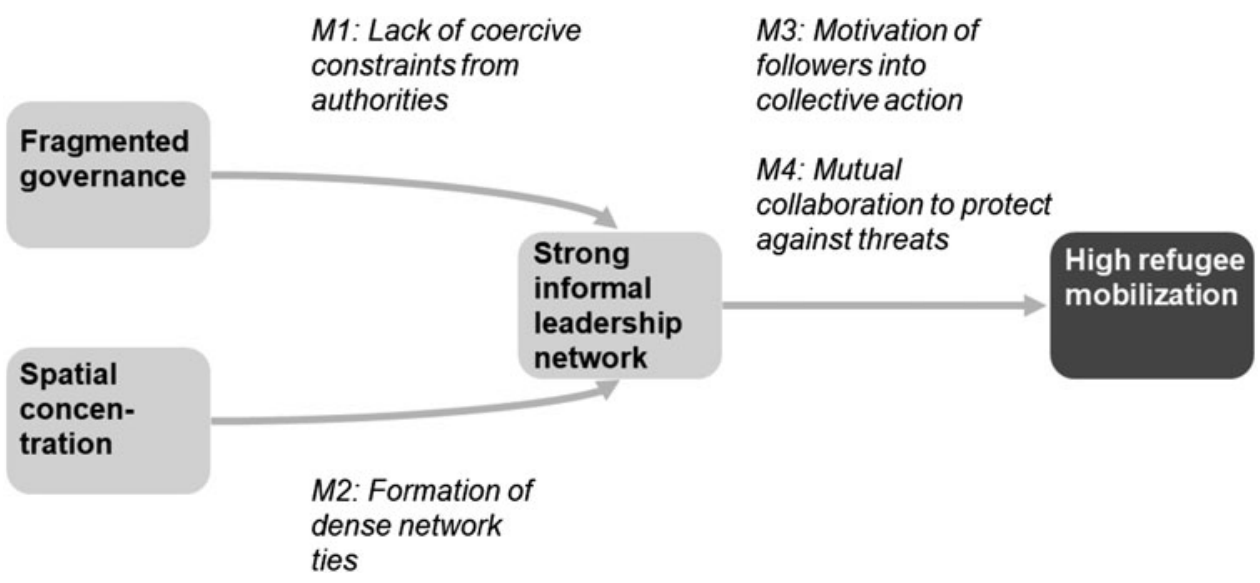


the summer of 2015 with refugees, aid providers, and government representatives in Turkey, Lebanon, and Jordan; quantitative data on contentious events in each site; and UNHCR camp management documents. ${ }^{31}$

\section{Syrian Refugee Mobilization: Evidence from Jordan, Turkey, and Lebanon}

While the Syrian uprising began in early 2011 as a peaceful protest movement against the regime of Bashar al-Assad, by the end of its first year it had unraveled into a deadly civil war, causing tens of thousands of refugees to begin fleeing across the country's borders, primarily into Lebanon, Turkey, and Jordan. These countries set up three distinct regimes to manage the refugee inflows. In the following sub-sections I examine the relationship between governance structures, spatial configurations, informal leadership, and refugee mobilization in each of these sites. The findings from this analysis are summarized in figure 2, which depicts the scoring of each variable across cases.

\section{Mobilization in Jordan's Za'atari Camp}

The Za'atari Camp was opened on July 28, 2012, when the Jordanian government made a unilateral decision to begin settling refugees on an open stretch of desert in the north of the country. ${ }^{32}$ The population of the camp grew quickly. By the end of 2012 there were 55,000 residents, and the population peaked in April 2013 at roughly 200,000 residents. ${ }^{33}$ Incoming Syrians were met at the border by the Jordanian military and, after a brief registration process, were brought to Za'atari where they were collected into an area in the open desert surrounded by a small ditch.

The rapid settlement of large numbers of Syrians into this contained space put tremendous pressure on the organization that had been charged with the camp's management, the Jordanian Hashemite Charity Organization (JHCO), a pseudo-governmental aid and relief organization. According to one former JHCO official, the organization, which had almost no experience managing camps, was overwhelmed by the experience of having to open and run Za'atari. ${ }^{34}$ Lacking the capacity to run Za'atari on its own, JHCO sought help from various UN organizations and NGOs for myriad operational activities; UNHCR handled refugee registration, the World Food Program distributed food, UNICEF and Save the Children tried to set up schools, and the Norwegian Refugee Council distributed tents. ${ }^{35}$ These disparate organizations, with different experiences and mandates, often found themselves at odds over how to manage the camp, and decisions were uncoordinated and haphazard. For example, many of the humanitarian organizations took what one UN officer described as an "infrastructural" approach

\section{Figure 2}

\section{Truth table of cases and variables}

\begin{tabular}{|c|c|c|c|c|}
\hline \multirow{3}{*}{ 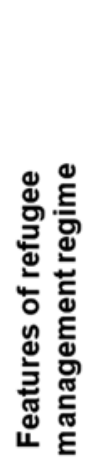 } & & $\begin{array}{l}\text { Jordan - } \\
\text { Za'atari Camp }\end{array}$ & $\begin{array}{l}\text { Turkey - } \\
25 \text { refugee camps }\end{array}$ & $\begin{array}{l}\text { Lebanon - } \\
\text { Informal tented settlements }\end{array}$ \\
\hline & $\begin{array}{l}\text { Governance } \\
\text { structure }\end{array}$ & $\begin{array}{l}\text { Fragmented } \\
\text { Myriad uncoordinated } \\
\text { organizations sharing } \\
\text { governance responsibility }\end{array}$ & $\begin{array}{l}\text { Consolidated } \\
\text { Governance by centralized, } \\
\text { high-capacity government } \\
\text { agency (AFAD) }\end{array}$ & $\begin{array}{l}\text { Fragmented } \\
\text { Governance by myriad UN } \\
\text { and humanitarian } \\
\text { organizations }\end{array}$ \\
\hline & $\begin{array}{l}\text { Spatial } \\
\text { configuration }\end{array}$ & $\begin{array}{l}\text { Concentration } \\
\text { Refugees colocated into } \\
\text { the confined space of the } \\
\text { camp }\end{array}$ & $\begin{array}{l}\text { Concentration } \\
\text { Refugees colocated into the } \\
\text { confined spaces of the } \\
\text { camps }\end{array}$ & $\begin{array}{l}\text { Dispersion } \\
\text { Refugees dispersed in } \\
\text { small, vulnerable, and } \\
\text { disconnected settlements }\end{array}$ \\
\hline & $\begin{array}{l}\text { Informal } \\
\text { leadership } \\
\text { networks }\end{array}$ & $\begin{array}{l}\text { Strong } \\
\text { Autonomous informal } \\
\text { leaders ("street leaders") } \\
\text { connected in dense } \\
\text { networks }\end{array}$ & $\begin{array}{l}\text { Weak } \\
\text { Informal leaders } \\
\text { ("mukhtars") coopted and } \\
\text { closely monitored by camp } \\
\text { authorities }\end{array}$ & $\begin{array}{l}\text { Weak } \\
\text { Informal leaders ("shawish") } \\
\text { isolated and disconnected } \\
\text { from each other }\end{array}$ \\
\hline & $\begin{array}{l}\text { DV: Level of } \\
\text { mobilization }\end{array}$ & $\begin{array}{l}\text { High } \\
\text { Frequent and persistent } \\
\text { protests against camp } \\
\text { authorities }\end{array}$ & $\begin{array}{l}\text { Low } \\
\text { Rare and sporadic protests } \\
\text { immediately repressed by } \\
\text { security forces }\end{array}$ & $\begin{array}{l}\text { Low } \\
\text { Few refugee protests, } \\
\text { mostly occurring in the } \\
\text { largest informal settlements }\end{array}$ \\
\hline
\end{tabular}


to service provision, which he said they imported from their experiences with refugee crises in Africa. ${ }^{36}$ This approach emphasized "setting up the apparatuses of service provision," like facilities, logistics, and orderly processes, rather than distributing aid quickly and directly to residents, which was JHCO's preferred approach.

These differences in vision led to a profound lack of coordination in camp management. Indeed, not only did the various organizations disagree, but they would sometimes actively undermine each other. For example, on one occasion in the winter of 2012, a UN organization received a donation of caravans from Saudi Arabia but decided not to distribute them directly to residents, instead stashing them in an area enclosed by fences at some distance from the camp. That night there was a rainstorm and after residents appealed to JHCO for better shelter, its officials urged them to break down the fences and take the caravans for themselves. ${ }^{37}$ Another piece of evidence pointing to the disarray of the initial governance system is that in March 2013 JHCO decided to hand management responsibilities over to UNHCR, which had far more experience running refugee camps. The new camp director, Kilian Kleinschmidt, chaired his first CMC meeting on March 19, 2013. At this gathering he chastised his Jordanian and international partners for their poor collaboration over the previous months, and emphasized the need to improve accountability: "We need to work together, in a spirit of teamwork and partnership, with UNHCR coordinating . . . . It's important that we have clarity of organisation and responsibilities." 38

The extreme fragmentation in Za'atari's initial governance model undermined the humanitarian and governmental organizations' ability to shape the development of the camp as it grew, monitor the daily activities of its residents, or sanction refugees who broke the rules. The authorities in charge maintained a limited presence in the camp; indeed in the early days they rarely entered the camp at all, instead distributing food and non-food items from a central point at the main gate. ${ }^{39}$ With no authorities to monitor or sanction them, residents frequently violated official camp policies. For example, though the aid organizations tried to direct Syrians to set up their tents and caravans along an orderly grid-like model, residents would move their makeshift dwellings to areas where they preferred to live (often near relatives or members of their home villages). ${ }^{40}$ Residents also tapped into the camp's electricity lines to secure private access to electricity; they refused to use public kitchens and bathrooms, instead building private versions in their own homes; they inserted hoses into public water tanks to fill their own private tanks; and they opened their own businesses despite the Jordanian government's legal prohibitions. ${ }^{41}$ An important reason that residents were able to break the rules with such impunity was that for more than a year and a half after its opening Za'atari maintained no regular police force. ${ }^{42}$ Instead, security was provided by two quasi-military organizations: the Jordanian gendarmerie and a Bedouin paramilitary regiment called the Royal Badia Forces. Neither force had any experience with policing and, like the aid organizations, they maintained no regular presence in the camp. Rather, they remained stationed at the periphery of the camp, only entering when there was unrest, which they typically quelled with teargas. ${ }^{43}$ One aid worker who was present during these early days described the security system as follows:

The Bedouin forces were not able to control things in the camp. They often tried to get something under control but then they would be pushed aside and they would have to withdraw. Eventually the gendarmerie began getting involved and they were able to control things better but they took a very heavyhanded approach. They used tear gas. There were so many times when I had teargas in my eyes from them putting down riots. ${ }^{44}$

The regular use of such heavy-handed security tactics to quell dissent demonstrates that for the authorities controlling Za'atari it was not a lack of will that shaped their handsoff security approach —rather it was a lack of capacity due to the weakly consolidated governance system.

The vacuum of authority and control in the camp quickly came to be filled by leaders within the refugee community, who began to establish their own informal system of governance. These leaders generally had one of two profiles. ${ }^{45}$ In some cases, they were figures who had held positions of authority back in Syria, mostly as the heads of large families or leaders of villages or clans. For example, one leader in District 8 who had been a trader in a town outside Dera'a, arrived in Za'atari in early 2013 with 50 members of his extended family, who all settled into the same district. ${ }^{46}$ In other cases, leaders built up their authority within the camp itself-they became known as individuals who could solve problems, get things done, or access goods, which was particularly important for residents suffering from the humanitarian organizations' haphazard aid distribution practices. Many of them amassed considerable resources by running smuggling operations or informal businesses, including shops on the camp's main street, the "Champs Elysée." 47 These informal businesses practices, and the tendency for leaders to distribute resources differentially to their families and constituents, led some humanitarian officials to characterize them as mafia-type figures. ${ }^{48}$ Though camp authorities were aware of these illegal activities and alarmed at refugee leaders acquiring autonomous bases of power, their ineffectual security system and lack of policing capacity left them without the means to rein these leaders in.

Though these leaders mostly had not known each other before moving to Za'atari, their close proximity in the camp meant that they interacted frequently and got to know each other quickly. Within a few months they had worked out their own informal system of governance, with each leader taking responsibility for a particular street (the source of the informal epithet, "street leaders," by 
which they were known). ${ }^{49}$ Although in some instances a leader's efforts to assert control over a street were resented by certain residents, they rarely resorted to violence. And overall the system they worked out was welcomed, as it brought a degree of order and stability to the chaos of the camp's early days. ${ }^{50}$ Hierarchies also emerged: street leaders in a particular district would select one member to become a district leader, with authority over potentially thousands of residents living in a single camp district. Describing one former district leader, an NGO worker noted that he had "controlled so many people in the camp. The other street leaders supported him because he is respected and has the most authority." ${ }^{51}$ The street leaders in a district would gather often to socialize and jointly work out disputes. For example, two street leaders in District 8 , who met each other in the camp because they had settled in the same district, described how they collaborated to mediate disputes between families or fights between young men. ${ }^{52}$ They came to serve as hubs at the center of camp districts; they would typically procure an extra trailer which then provided a gathering place for members of the community.

Two documents drafted by UNHCR in the months after it took over management of the camp provide additional evidence beyond interview data that the street leader system emerged due to the close physical proximity of leaders in the camp and the general vacuum in authority. The first, the "Zaatari Governance Plan," outlined UNHCR's vision for re-imposing order on the camp, and the second, the "2013 Safety and Security Report," provided an overview of safety and security concerns through 2013. ${ }^{53}$ A section on "Camp Management" in the "Safety and Security Report" discusses the reasons behind the turnover in management from JHCO to UNHCR. It notes that one of the biggest problems with the early governance regime was that "'humanitarian' or perhaps more specifically 'public' space... . [was] arguably long contested between some of the longer-staying informal refugee leaders and the camp management." ${ }^{54}$ In another section of the report, the rise of the "street leaders" governance system is said to have originated "from the absence of formal authority and decentralized humanitarian structures, which lead to street leaders being born. The majority of whom were self-appointed." ${ }^{\text {5 }}$ Similarly, the "Zaatari Governance Plan" explains that in the year following the camp's opening the rapid inflow of refugees had forced camp management to focus its efforts on "lifesaving activities" like providing shelter, food, and water, and that contact with residents was typically only at arrival or during aid distributions. It goes on:

As a result, refugee community structures - the mechanisms through which refugees manage their day-to-day lives-have grown up spontaneously. In some cases these are clustered around groups with a common place of origin in Syria, who are able to provide reciprocal support and protection. In others, powerful individuals and organized gangs have imposed their will on sections of the camp, diverting assistance and engaging in criminal activities ... With limited avenues for dialogue with aid agencies and the GoJ, refugees tend to express frustration through demonstrations and violence. Change is pursued through force and pressure. [There is a] stated belief by some criminal and political groups that Zaatari is now 'Syrian territory', viewing interventions by Jordanian security inside the camp as a threat to their hegemony. ${ }^{56}$

As the final sentences of this excerpt suggest, the rise of street leaders in Za'atari was followed by a marked escalation in contentious events-including demonstrating, rioting, stone-throwing, blocking roads, and occupying buildings. In many instances, street leaders used their considerable influence among their constituents and their control over resources to motivate camp residents into action. For example, street leaders worked together to mobilize members of camp districts who had been denied access to a particular good or service, like electricity, caravans, or clean water. ${ }^{57}$ Often these protests occurred at the main gate of the camp, which was the site of most aid distributions. ${ }^{58}$ Street leaders would also encourage residents to defend single members of their communities who had been affronted or aggrieved-as depicted in the opening vignette of this essay, when several refugees from a particular family were detained. Sometimes they organized protests for more nefarious reasons: one NGO member explained that street leaders would sometimes pay children to throw stones during a distribution to create a diversion and draw in security forces, while they engaged in an illegal undertaking elsewhere in the camp. 59 They would also deliberately disrupt distributions so they could siphon off extra food or goods, which they would then sell. ${ }^{60}$ Sometimes they fomented riots so that they could step forward and serve as mediators, therefore positioning themselves as indispensable in front of camp authorities. ${ }^{61}$ Street leaders from a particular district also worked together to protect each other from security forces. If one was arrested or detained, others would stage a demonstration in response, and when security forces intervened to quell a protest, leaders would mobilize even more followers to intimidate them and force them to retreat. ${ }^{62}$ Though sometimes unrest in Za'atari did emerge spontaneously, without the specific sponsorship of street leaders, interviewees were consistent in attributing much of the unrest to the active efforts of these figures. ${ }^{63}$

One example relayed by security officials in the camp is relatively representative of the type of events that occurred. Water in the camp was distributed by a Jordanian contractor who would regularly fill large public water tanks. The trucks used to carry the drinking water were generally painted green, to distinguish them from the orange trucks used to cart out wastewater from the communal toilets. In one incident a resident in District 6 noticed something odd about one of these green trucks and, with a stone, scraped the paint away from the side of 
the truck's water tank, revealing an orange undercoat. The truck was a sludge removal truck that had been hastily repainted green and re-appropriated to distribute drinking water. The resident called the local street leader on his mobile phone, and quickly a crowd of 400 people gathered. They began throwing stones at the tank driver and threatening to kill him. Shortly thereafter the gendarmerie and camp police arrived. They entered into negotiations with several street leaders and, after learning what happened, they arrested the truck driver and the street leaders encouraged the assembled crowd to disperse.

By the beginning of 2013, protest had become the de facto channel for refugee communities to air their grievances to camp authorities. The persistence of such contention is reflected in data collected by the UN for its Safety and Security Reports. These reports include every event reported to UNHCR by the security forces and humanitarian organizations working in the camp, including incidences of protest, disorder, gatherings, sit-ins, and stone-throwing. ${ }^{64}$ Figure 3 plots the number of events by type for 2013 and 2014. It points to the consistency of protest through this period, with stone-throwing incidents representing the majority of events (45\%), followed by protests $(25 \%)$. Though some of these events, like stonethrowing and disorder, seem to suggest contention of a more spontaneous and disorganized nature, many interviewees noted that even in these instances street leaders often played an organizing role (for example, by paying children to throw stones at NGO workers).

One question that the figure raises is why contention appears to have declined beginning in summer 2013. That deceleration coincides with the new camp management's deliberate efforts to reach out to street leaders and incorporate them into camp governance. Although some camp administrators were wary of working with street leaders, the camp director Kilian Kleinschmidt became convinced that the only way to bring order to the camp was by recognizing street leaders' authority and working with them in camp administration. ${ }^{65}$ He held frequent ad hoc meetings with street leaders, which for much of 2013 and 2014 served as the primary forum through which differences between refugees and camp management were negotiated. ${ }^{66}$ This new pattern of interactions provided a semi-formal communication channel that had not existed before, and camp authorities essentially gave up on trying to curtail street leaders' illicit activities. ${ }^{67}$ Under these new terms, leaders had far fewer reasons to resort to contentious methods to press their claims; they maintained their authority and became UNHCR's de facto partners in camp governance.

\section{Quiescence in the Turkish Refugee Camps}

Like in Jordan, the Turkish government's initial response to the Syrian refugee crisis was centered on housing Syrians

\section{Figure 3}

Number of monthly contentious events in Za'atari camp (2013 and 2014)

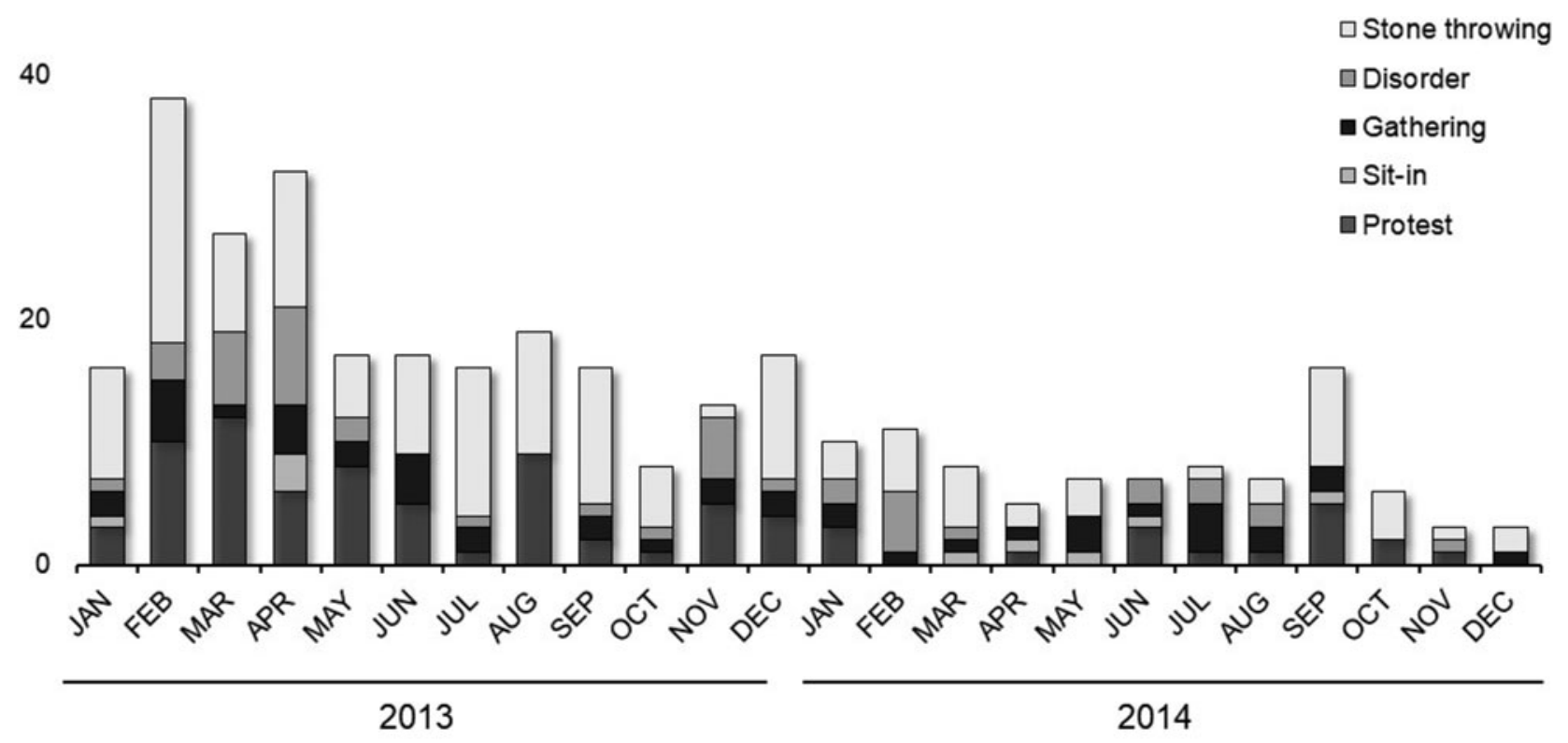

Source: UNHCR, "Zaatari Refugee Camp: 2013 Safety and Security Report," March, 2014; UNHCR, Field Safety Unit (Jordan), "Safety and Security Report (2014)," 1 February, 2015. 
in refugee camps, and by mid-2015 it was operating 25 camps along its border with Syria. The largest of these camps had populations in the tens of thousands, while some of the smaller ones housed only several thousand refugees. ${ }^{68}$ Yet in contrast to Za'atari, concentration in the case of the Turkish camps did not facilitate the rise of strong informal leadership networks, and there were few reported examples of refugees mobilizing to make claims or raise grievances with authorities. ${ }^{69}$

The weakness of the Syrian communities in Turkish camps can be attributed to the well-consolidated governance systems that administered these spaces, which precluded the emergence of autonomous leadership networks. Shortly after the uprising broke out, the government in Ankara assumed sole responsibility for managing refugee inflows. The camps that it constructed along its border were run by a government agency under the Prime Minister's office- the Disaster and Emergency Management Presidency (AFAD). This agency was closely linked to the central government and received significant funding and support. It had a strong mandate, a significant budget, a competent managerial corps, and the ability to dictate terms to subsidiary government agencies. ${ }^{70}$ It appointed one camp director and two vice directors to run each camp, who then delegated tasks to a small number of security and service provision organizations, all with ties to the government. ${ }^{71}$ Security was provided by the Turkish Jandarma and a private security company. Most significantly, AFAD declined repeated offers of assistance from UNHCR and international NGOs, insisting that it was able to run and manage the camps on its own. ${ }^{72}$ There were therefore far fewer agencies and organizations operating in the Turkish camps than in Za'atari, and those that were there were closely managed by the AFAD representatives.

AFAD's strong mandate and top-down management approach allowed it to closely monitor and control life in its camps from the beginning of the crisis. ${ }^{73}$ According to one UN worker who had been providing regular support to schools in the camps since 2013, the camps were extremely well resourced and the security environment was "tight" and "controlled." 74 The heavy-handed security approach was also confirmed by a Turkish official who had been involved in managing the five camps in Hatay governorate. Two of these camps were the first to be opened by the Turkish government, and during these early days several incidences of unrest occurred. But the official stressed that these incidences were dealt with harshly:

In the beginning there was some unrest; sometimes families would quarrel with each other and sometimes there was trouble because they believed aid was being distributed unevenly. But now we have full control over the camps. At the beginning there were these troublemakers; but we exiled them. Now we have security cameras, and security personnel that go into the camp whenever there's a problem. ${ }^{75}$
The practice of exiling "troublemakers"-either to non-camp settings in Turkey or, in extreme cases, back to Syria - was documented in at least one other context. In the aftermath of the biggest recorded protest in a Turkish refugee camp-when hundreds of people gathered in front of the camp's administrative building after a child died from a fire caused by faulty electrical wiring - the Turkish authorities used security camera footage to identify those involved and deported 600 refugees back to Syria. ${ }^{76}$ The Turkish authorities also maintained a much higher ratio of police and security personnel to refugees than did the authorities in Za'atari, and these security forces were directly accountable to AFAD's camp directors. For example, in the Hatay camps approximately 100 security officials monitored camps of 3,000 to 4,000 residents; by contrast, roughly the same number of security forces were tasked with monitoring the 100,000 plus residents of Za'atari in early 2013 . $^{79}$

The contrast in levels of governance between Za'atari and the Turkish camps was also reflected in the different spatial layouts of these settlements. ${ }^{78}$ Space in the Turkish camps was organized according to the well-ordered logic of high-modernist urban planning: containers or tents were clustered into symmetrical blocks, separated by wide and open paved streets. ${ }^{79}$ In contrast, the refugees in Za'atari resisted such deliberate planning schemes, and reorganized the space of the camp into dense and haphazard streets, with creatively designed living compounds, which better suited their needs and more closely approximated their living conditions in Syria. ${ }^{80}$ Relatedly, the main streets of Za'atari, particularly the Champs Elysée, were bustling with life, as residents shopped and mingled at the hundreds of illegal stores and markets that cluttered the street (all operating out of appropriated trailers). No similar refugee businesses were allowed in the Turkish camps. Further, the Turkish camps were surrounded by double barbed wire fences, as opposed to the easily passable ditch that surrounded most of Za'atari. And Syrians in Turkish camps lived under the constant surveillance of security cameras, whereas Za'atari had no such sophisticated mechanisms of panoptic control.

With such tight control over their lives, the refugees living in the Turkish camps did not develop leadership networks with autonomous loci of power. Rather, the leaders that did emerge were appointed by the camp authorities, and served more as mechanisms for demobilization than as independent leaders. AFAD devised a governance system in early 2013 whereby every three to seven streets would elect a "mukhtar," who would help the camp authorities by distributing aid and information to their districts. ${ }^{81}$ In some ways these men did approximate the street leaders of Za'atari; they were typically community leaders who had been active in the camp or who had been tribal or village elders. ${ }^{82}$ A key difference, though, was that their positions were, from the beginning, created and endorsed formally by the AFAD 
administrators, and their power was tied largely to these official designations. They were monitored closely by the authorities to ensure they did not gain too much autonomy. ${ }^{83}$ Eventually, AFAD introduced a rotation system, whereby no leader could serve as mukhtar for more than one year, to ensure that power did not become overly concentrated ${ }^{84}$ In this sense, the mukhtars in the Turkish camps were a set of coopted leaders, unable or unwilling to mobilize their communities or square off against the powerful authorities who ran the camp.

\section{Lebanon's Dispersed Refugees}

In Lebanon, the response to the Syrian refugee crisis was in many ways the opposite of Turkey's. The Lebanese government at first refused to establish a legal and policy framework for managing the influx of refugees. The government provided little direct aid or relief, in part because it is itself weak and divided, with limited capacity in many parts of Lebanon. It allowed UNHCR and NGOs to fill this gap, but its lack of involvement meant that there was little centralized coordination of aid activities. One policy that was consistently applied throughout the crisis was a prohibition on formal refugee camps, a rule that was directly informed by Lebanon's troubled history with Palestinian refugee camps. ${ }^{85}$

As in Turkey, Lebanon's refugees developed weak leadership networks and there were few incidents of protest. Interviews with Syrians, researchers, academics, government officials, UN organizations, and NGOs all confirmed that there were few strong refugee leaders, and very few incidences of refugees making contentious claims against authorities. These conclusions are supported by event data scraped from publicly available news, Internet, and social media sources from February 2014 to January 2017 , which include only eighteen examples of contentious events involving Syrians in all of Lebanon. ${ }^{86}$ The factors responsible for these low levels of mobilization were, however, different than those in Turkey. Because the Syrians in Lebanon were prevented from concentrating in one place, they were unable to develop the kinds of dense leadership networks necessary to support mobilization.

With no formal camps for them to move into, many Syrians in Lebanon set up settlements wherever they could, typically on vacant strips of land or near farms where they had once been seasonal laborers. These informal settlements represented the most concentrated settlements of refugees in Lebanon, and were the closest analogues to the Turkish and Jordanian camps. At the end of 2014 there were 1,421 informal settlements in the country, each of whose resident populations rarely surpassed $1,000{ }^{87}$ Technically when refugees settled they fell under the authority of local Lebanese governors, who were given free rein to manage the Syrian communities as they saw fit. ${ }^{88}$ In fact, aid and services were provided through a byzantine system in which local and international NGOs, as well as government ministries and UN organizations, shared responsibilities for particular regions and sectors. ${ }^{89}$ There was no consistent security presence in these camps, although occasionally the Lebanese police forces would detain or harass refugees. In this sense the governance regime was even more fragmented than the regime that governed Za'atari in its early days.

But despite this fragmented governance, dense informal networks did not emerge in Lebanon, as the physical isolation and distance between refugee settlements prevented the kind of networking and relationshipbuilding that had characterized Za'atari's communities. Syrians generally remained in their informal settlements, in part due to a focus on meeting daily needs and in part due to concerns about being harassed at checkpoints or arrested for holding out-of-date papers. ${ }^{90}$ They therefore formed few relationships with Syrians in other locations, even when neighboring settlements were only several kilometers away. ${ }^{91}$ According to one Syrian activist who spearheaded an effort to organize five of the Syrian settlements in the Bekaa, the distance between the communities and the challenges to moving around were major barriers to mobilization. $\mathrm{He}$ and several other Syrians tried to build networks between the five settlements, establishing a community center in the largest one where refugees could discuss shared concerns and organize themselves. But the initiative was a failure; the settlements were too far apart and transportation back and forth was difficult. ${ }^{92}$ Similarly, NGOs focusing on "community mobilization" and "social protection" tried to bring together Syrians living in clusters of settlements to form committees that could represent their communities to authorities and coordinate demands. Most of these initiatives succeeded only for as long as the NGOs provided direct support. ${ }^{93}$ Other research efforts have similarly found that Syrians in Lebanon lacked robust community structures, and that this was driven by the physical dispersion of their settlements. ${ }^{94}$

The only informal leaders to emerge in Lebanon were a category of figures that the aid community termed "shawish." Shawish were in many ways analogous to Za'atari's street leaders and the Turkish mukhtars: they were figures of authority whose power derived from their preexisting social prominence or their ability to get things done. ${ }^{95}$ Each camp typically had one shawish, who may have been the head of the largest family or had the strongest relationship to a Lebanese landlord. However, networks of shawish never emerged; each shawish exerted control over his own camp or settlement, and maintained few ties with those in other areas. ${ }^{96}$ As in Za'atari, a fragmented governance regime allowed these shawish to act relatively autonomously and to serve as resource brokers. Indeed, in many cases they came to serve as intermediaries between refugee communities and aid organizations, who relied on shawish for aid distribution. ${ }^{97}$ 
But because their constituencies were relatively small and their networks limited, they could not build the kind of complex social structures that facilitated mutual collaboration and sustained mobilization in Za'atari.

\section{Alternative Explanations}

I have argued that the concentration of Syrian refugees in the Za'atari Camp under the control of myriad uncoordinated agencies facilitated the rise of informal leaders who were able to mobilize their communities. But there are at least two other theories that could plausibly explain this variation, both of which appear in anthropological studies of refugee mobilization in other sites. The first is that refugees in Za'atari protested because they held deeper grievances than those in other camps due to worse conditions. ${ }^{98}$ But regional patterns in refugee living conditions do not provide much support for this theory. In Turkey it is true that camp-based refugees encountered relatively clean and safe living conditions, though interviews and third-party accounts still documented significant grievances among refugees, who complained mostly about the lack of freedoms and restrictions on movements (a reflection of the camps' consolidated governance and high levels of policing). ${ }^{99}$ But even if conditions in the Turkish camps were better than in Za'atari, in Lebanon, the other site of low mobilization, conditions for refugees were widely acknowledged to be the worst in the region. ${ }^{100}$ Refugees in Lebanon faced deep economic and physical insecurity, with hardships that included a lack of economic opportunities, hostile host communities, poor housing, and a lack of access to basic goods and healthcare. ${ }^{101}$ Although conditions in Za'atari, particularly when the camp first opened, were far from ideal, they certainly were no worse than the dire circumstances facing Syrians in Lebanon. Grievances, then, cannot explain differential levels of contention across these sites.

Another plausible counter-explanation is that there was something unique about the social histories, identities, or experiences of the refugee communities in Za'atari that made them more likely to protest in the first place. ${ }^{102} \mathrm{We}$ can evaluate this explanation by considering the most important ways in which these refugee communities might differ. First, it might be that the refugees in Za'atari were from a higher class background than those in Lebanon and Turkey. In fact, the data indicate that this was not the case -refugees living in camps in Turkey, Lebanon, and Jordan were almost all drawn from a similar class position, with lower incomes, rural livelihoods, and no more than secondary education. They also shared the same linguistic and religious profile - almost all were Sunni Muslim Arabs, the majority ethnic group in Syria. ${ }^{103}$

A second possibility is that refugees from regions with stronger social networks, like clan ties or tribal structures, or who had previous experience with contention were the ones who mobilized in exile. Indeed, a February 2015 analysis of the demographics of the Za'atari Camp found that $82 \%$ of camp residents come from the region of Dera'a, which was the site of the first protests against the Asad regime. ${ }^{104}$ Perhaps the Dera'awis who settled in Za'atari leveraged the strong social networks that allowed them to initiate protest in the first place. But, again, the empirical patterns within and across cases do not provide much support to this explanation. First, as discussed earlier, many street leaders that emerged in Za'atari were not authority figures before the war but rather built up their influence after arriving in the camp. If preexisting social networks were the cause of Za'atari's strong informal leaders, we would expect to see the majority of these leaders drawing their authority from social contexts that predated their exile. Second, within Za'atari the same forms of authority emerged even in districts (like Districts 7 and 8) where residents hailed from regions other than Dera'a. ${ }^{105}$ Third, in other camps and regions in Jordan, Dera'awis similarly made up the majority of residents, yet there was far less protesting. For example, a second Jordanian camp, the Azraq Refugee Camp, was opened in April 2014, and was set up with a governance regime that approximated those in the Turkish camps. ${ }^{106}$ Yet despite having a large numbers of Dera'awis, Azraq saw consistently low levels of mobilization. ${ }^{107}$ The same can be said of the Emirates Jordanian Camp, a smaller camp of 5,000 residents, of which over $50 \%$ of residents were Dera'awi. ${ }^{108}$ Similarly, in Irbid Province, where in 2015 $77 \%$ of the Syrian population was Dera'awi, there were very few contentious episodes, both in the two camps located in the province and among the non-camp Syrian population. ${ }^{109}$ Finally, across the other two cases examined here-Lebanon and Turkey-refugee place of origin had little effect on levels of mobilization. Both countries' camp-based refugees hailed from diverse regions, yet despite this diversity refugee mobilization patterns were uniformly low. ${ }^{110}$ Indeed, in some camps, like those in North Lebanon, over $80 \%$ of the population came from Homs, a Syrian city that, like Dera'a, has dense tribal structures and rose up early against the Asad regime- - yet these camps witnessed few protests. ${ }^{111}$ In short, were region of origin the primary driver of mobilization we would expect to see protest emerge among refugee populations from the same place, or from places with similar characteristics - yet we do not. Dera'awis (and non-Dera'awis) protested in Za'atari but not elsewhere, and in other countries, levels of mobilization were uniformly low, regardless of place of origin.

\section{Conclusion}

Despite the often harsh circumstances of their displacement, the preceding analysis suggests that under certain conditions refugees may in fact mobilize politically. Where they are able to form strong and autonomous 
informal social structures, they may organize to pressure governments and other authorities, demand rights, or negotiate for better services. Such dynamics are important because they shape the political relationship between refugees and the governments and communities who host them, and set the course for long-term trajectories of integration and political engagement. The findings here are also important for debates regarding the appropriate scope and nature of humanitarian aid practices in managing refugee crises. Critics of humanitarian actors have pointed to the often authoritarian nature of humanitarian management and the unwillingness of aid organizations to recognize the political dimensions of refugee crises-arguments that this study in many ways supports. ${ }^{112}$ Yet while the conditions supporting mobilization in Za'atari were mostly accidental artifacts of Jordan's particular humanitarian regime, one could imagine a humanitarian system specifically designed to foster and support the mobilization processes that this study has identified. Indeed, to the extent that most humanitarians would almost certainly endorse the goal of empowering refugees, this study may hold some important (albeit uncomfortable) lessons about how to go about achieving this goal, perhaps with considerably less violence and chaos than characterized the Za'atari experience. ${ }^{113}$

More broadly, the logic of how spatial concentration and fragmented governance facilitate the rise of informal leadership networks may provide a framework for understanding how marginalized communities in general manage to develop the social strength necessary to resist powerful authorities. Many social groups, including peasants, migrants, laborers, slum-dwellers, and prisoners, face the same types of barriers to mobilization that plague refugee communities - they lack access to financial and non-financial resources and they have few rights or little formal influence over authorities. Given these challenges it is surprising how frequently such groups manage to protest. The argument presented here-that informal leadership networks help to solve these challenges, and that these networks emerge in spaces of physical concentration where authority structures are fragmented and uncoordinated-may shed light on where and when we should expect to see mobilization by these types of groups. Put another way, where social groups face conditions of low resource access and political vulnerability, we should expect to see the combination of spatial concentration and fragmented governance produce strong informal leadership networks capable of supporting political mobilization.

Indeed, scholarship on an array of groups in which these scope conditions hold, including peasants, urban slum-dwellers, and prisoners, have proffered findings suggesting that this logic may hold elsewhere. For example, in their studies of the urban poor Asef Bayat and Diane Singerman have both highlighted the important role that space can play in facilitating the rise of dense social networks. ${ }^{114}$ They show that close social relations and strong networks can serve as alternatives to physical resources in supporting mobilization, and that certain urban spaces help to produce such networks. Similarly, an older literature on peasant mobilization identifies space and rural isolation as factors explaining why certain types of peasants are more "revolutionary" than others. ${ }^{115}$ These studies stress that the relative isolation and autonomy of smallholding peasants allows them to organize outside the reach of government control. In addition, villages themselves provide a space in which peasants form strong networks and close solidary relationships, which in turn provide them with the organizational strength to resist repression. Finally, those who have examined prison riots have similarly identified conflicts and divisions within prison management authoritiestypically between wardens and guards - as a key factor that facilitates the mobilization of inmates. ${ }^{116}$ They also point out that prisons, which-like camps-are total institutions that concentrate individuals into a confined space, may paradoxically facilitate the rise of mobilizing networks.

Though these studies provide only suggestive evidence to support the portability of my explanation, they do indicate that the processes that conspired to produce Za'atari's informal leaders may be at work in other social sites and among other social groups. Although I do not claim to offer a theory that comprehensively explains mobilization among the dispossessed, I do suggest that where communities are grouped together and left to their own devices, strong informal leaders are likely to emerge, and that these leaders may help such marginal groups overcome otherwise considerable barriers to mobilization.

\section{Notes}

1 CMC Meeting Minutes, Za'atari Refugee Camp, 4 August 2014.

2 Ibid.

3 Interviews J.10 and J.15. Interviewees are referenced in footnotes with unique identifiers. Full details about each interviewee can be found in online Appendix A.

4 UNHCR 2014, UNHCR 2015 a.

5 Migdal 1988.

6 Wolf 1969; Paige 1975; Scott 1977.

7 Piven and Cloward 1978; Snow and Cress 2000.

8 Gay 1994; Auyero 2001; Jha, Rao, and Woolcock 2007; Auerbach 2016.

9 Dowty and Loescher 1996; Posen 1996; Salehyan and Gleditsch 2006; Muggah 2006; Salehyan 2008.

10 Stedman and Tanner 2003; Lischer 2005.

11 Onoma 2013.

12 Dancygier 2010 and Koopmans et al. 2005.

13 Dancygier et al. 2015 and Dancygier 2017.

14 Dancygier 2010 and Vernby 2013. 
15 Malkki 1995; Hyndman 2000; Horst 2006; Feldman 2008, 2012; Agier 2011; Holzer 2015; Rawlence 2016.

16 Tilly 1978, 69.

17 McAdam, Tarrow, and Tilly 2001.

18 I consider both peaceful and unarmed violent action because, as scholars of contentious politics have often noted, the differences between these two types of claims-making are often subtle, with some repertoires difficult to categorize (e.g., stone-throwing, which was a common repertoire in Za'atari). Moreover, contention fomented by marginalized groups like refugees often fluidly combines violent and nonviolent tactics, as it tends to be less deliberate and orchestrated than the campaigns of explicitly nonviolent movements. I do not, however, consider armed violent incidents, which conceptually fall into a separate category of militarized action. Indeed, I found little evidence of militarized action against host country authorities in any of the three sites (though some refugees were planning to return to fight in the war).

19 McCarthy and Zald 1977; Jenkins 1983.

20 Olson 1965.

21 Gould 1993; Marwell, Oliver, and Prahl 1988; Marwell and Oliver 1993; McClurg 2003.

22 Gould 1995.

23 Marwell, Oliver, and Prahl 1988; Siegel 2009.

24 E.g., Migdal 1988.

25 Both Agier 2011 and Barnett 2013 note that in humanitarian crises the UN and NGOs have often taken on governance responsibilities typically associated with the state.

26 The idea draws on theories of political opportunities in the social movements literature. See Eisinger 1973; McAdam 1982; Kitschelt 1986; Tarrow 1998.

27 A similar logic is laid by Evans and Boyte 1986 and Poletta 1999 in their discussion of how "free space" may facilitate collective action.

28 Goffman 1961; Foucault 1971; Agamben 1998; Netz 2010.

29 On the integration of process tracing and the comparative method see Slater and Ziblatt 2013 and Falleti and Mahoney 2015.

30 In each case, camp-based refugees represented $\sim 20 \%$ of the total refugee populations at the time of the study. While there are downsides to focusing on this more limited sample of the refugee population, I accepted this tradeoff in order to achieve a "cleaner" comparison across cases.

31 For a fuller discussion of the research design and data collection methods see Appendix B.

32 Interview J.18.

33 By June 2014 the population of the camp had stabilized at roughly 80,000 . All camp population data were collected from UNHCR's data-sharing portal: data.unhcr.org/syrianrefugees/.

34 Interview J.20. JHCO's lack of preparedness was also noted by other interviewees present at the opening of the camp: Interviews J.04, J.15, and J.19.

35 Interviews J.04, J.15, and J.24.

36 Interview J.04.

37 Interview J.20.

38 CMC Meeting Minutes, Za'atari Refugee Camp, 19 March 2013.

39 Interviews J.15 and J.20.

40 Interviews J.15 and J.24.

41 Interviews J.10, J.15, J.16, J.17, J.24 and J.27.

42 Interview J.10.

43 Interviews J.10, J.15, and J.20.

44 Interview J.20.

45 Interviews J.08, J.19, J.22, J.23, and J.27.

46 Interview J.23.

47 Interviews J.13 and J.22. The street was named after the French-run hospital on its northeastern side.

48 Interviews J.07 and J.19. Indeed, some residents complained about the leaders' tendency to distribute resources only to their followers or to demand payments in exchange for services. Interview J.08.

49 For further discussion of the street leaders, including their relationship to camp management, see Sullivan and Tobin 2014.

50 Interviews J.08 and J.09.

51 Interview J.07.

52 Interviews J.22 and J.23.

53 UNHCR 2013a; UNHCR 2014.

54 UNHCR 2014, 10-11.

55 Ibid, 13.

56 Ibid, 4.

57 A review of minutes from the weekly CMC from November 2013 to October 2014 revealed that the majority of events occurred over problems relating to the following four issues: water/food, shelter, gas/ electricity, and security violations.

58 Interviews J.15 and J.20. For a video of a protest staged over electricity shortages in part of the camp, which includes a heated argument between Kilian Kleinschmidt and one of the street leaders, see https://www.youtube.com/watch? $\mathrm{v}=$ QbuBmYuledI.

59 Interview J.17.

60 Interview J.15

61 Interview J.07.

62 Interview J.10.

63 Interviews J.08, J.10, J.13, J.15, J.19, and J.21.

64 Numbers for January and February 2013 are likely underreported, as the reporting cadences had not yet been fully established.

65 CMC Meeting Minutes, Za'atari Refugee Camp, 19 March 2013. 
66 Interviews J.13, J.19, and J.23.

67 Interviews J.07, J.13, J.16, and J.19.

68 The populations of the largest two camps, Ceylanpinar and Akçakale, peaked in 2013 at 45,000 and 35,000, respectively. ACF International 2013, 6; Güçer, Karaca, Dinçer 2013, 16.

69 The lack of mobilization in the Turkish camps was confirmed by interviews and third party researchers. Moreover, a review of Turkish national and local newspapers from 2011 to 2014 identified only eight reported instances of Syrian protests or unrest.

70 Interviews T.15, T.17, and T.27.

71 Interview T.17.

72 Interviews T.12 and T.15.

73 This strategy aligns with the Turkish government's broader approach to the Syrian refugee crisis, which it has sought to manage carefully to serve its broader domestic and geopolitical goals. Indeed, refugees outside of camps are similarly monitored closely and challenges to the government are not tolerated.

74 Interview T.15.

75 Interview T.17.

76 Celikcan 2013; Kırmızıtaş 2013.

77 Interview T.17; UNHCR 2014, 15.

78 I thank Jillian Schwedler for suggesting that I analyze the spatial layout of the camps.

79 Scott 1998. On the use of high-modernist planning as a technique for asserting social control in refugee camps see Hyndman 2000 and Beehner 2015.

80 See also Beehner 2015.

81 Interviews T.17, T.24, T.25, and T.27.

82 Interview T.27.

83 Interview T.17.

84 Interview T.24.

85 For an explanation of the logic behind Lebanon's prohibition on camps see International Crisis Group 2013a, 16-18.

86 The data were scraped by the Lebanese data consultancy EQLIM; they are enumerated in Appendix C. Further, these data show that where events did occur they tended to be in places where there were greater concentrations of refugees and humanitarian governance was weak. For example, the greatest number of events occurred in Aarsal, a remote and inaccessible municipality in the north Beka'a Valley that took in large numbers of refugees.

87 World Food Program 2013, 13; Thibos 2014.

88 Interview L.14.

89 Interviews L.07, L.09, L.13, L.21, and L.26.

90 Interviews L.11, L.17, and L.21.

91 Interviews L.09, L.16, and L.21.

92 Interview L.11.

93 Interviews L.09, L.15, and L.29.

94 BRIC 2013; Search for Common Ground 2014; al-Saadi 2015; al-Masri 2015.
95 Interviews L.05, L.09, and L.19.

96 Interview L.11.

97 Interviews L.09, L.10, and L.22.

98 In their studies of Palestinian and Liberian camps Feldman 2008 and Holzer 2015 cite grievances with humanitarian policies as triggers for protests.

99 Interviews T.15, T.23, and T.25. For reports documenting such grievances see Özden 2013, 6; Erdoğan 2015, 60; International Crisis Group $2013 b$.

100 Two interviewees working on the refugee crisis at the regional level confirmed that conditions for refugees in Lebanon, particularly in ITS, were worse than in other countries, including in Za'atari; interviews R.1 and R.2.

101 On conditions in Lebanon see Norwegian Refugee Council 2013; World Food Program 2013; al-Masri 2015. In addition, several statistics reported by UNHCR as part of its Regional Refugee and Resilience Plan point to the poorer conditions in Lebanon. For example, in 2014, Lebanon had lower levels of education enrollment (30\%) than Turkey $(52 \%)$ and Jordan (85\%). It also had more refugees relying on food assistance programs, and its voucher values were lower than those for refugees in Turkey and in Jordan's camps. Moreover, Lebanon's refugees were sicker than those in Jordan, with a higher proportion of patients having communicable diseases. See 3RP Regional Monthly updates for January, February, and March 2015, available at http://www.3rpsyriacrisis.org/publications/regionalresponse-dashboards/, and UNHCR's 2013 "At a Glance: Health Data for Syrian Refugees," available at https://data2.unhcr.org/en/documents/details/ 40686.

102 Malkki 1995 discusses the importance of Hutu national identity in the construction of strong networks among Burundian refugees in Tanzania, and Horst 2006 places previous social networks and cultural practices at the center of her explanation for Somalis' strength in Kenya's Dadaab Camp.

103 Interviews T.06, T.08, T.09, L.19, L.24, J.08, and J.25. See also: AFAD 2013; BRIC 2013; al-Masri 2015; REACH 2014, 2015.

104 REACH 2015, 6.

105 For a map showing the regions of origin for each Za'atari district see: REACH 2015, 14. I also conducted interviews with street leaders from both Dera'a and Damascus, whose roles in their communities did not differ.

106 One UN officer described Azraq as a "concentration camp" compared to Za'atari. Interview J.04.

107 The UN reported only 5 "civil disturbances" from April 28, 2014 to December 31, 2014 in Azraq; UNHCR 2015a, 6. 
108 UNHCR 2013b.

109 See UNHCR 2015b. The camps are King Abdallah Park and Cyber City.

110 For data on place of origin among refugees in Lebanon and Turkey's camps see BRIC 2013 and Güçer, Karaca, and Dinçer 2013.

111 BRIC 2013, 34.

112 See, for example, Hyndman 2000, Terry 2002, Lischer 2005, Feldman and Ticktin 2010, Agier 2011, and Barnett 2013.

113 Beehner 2015 reaches similar conclusions based on his own examination of Za'atari.

114 Singerman 1995; Bayat 1997.

115 Wolf 1969; Scott 1977; Skocpol 1982.

116 Goldstone and Useem 1999, 2002.

\section{Supplementary Materials}

The below supplementary materials are available at https://doi.org/10.1017/S1537592718001020

Appendix A. Interviews Conducted

Appendix B. Qualitative Research Design and Data Collection Methods

Appendix C. Contentious Events Involving Syrian Refugees in Lebanon (2014-2017)

\section{References}

ACF International. 2013. "Joint Rapid Assessment: Humanitarian Crisis Syria + 5: Turkey.”

AFAD. 2013. "Syrian Refugees in Turkey, 2013: Field Survey Results.” Available at: https://www.afad.gov.tr/ upload/Node/2376/files/61-2013123015505-syrianrefugees-in-turkey-2013_print_12_11_2013_eng.pdf.

Agamben, Giorgio. 1998. Homo Sacer: Sovereign Power and Bare Life. Stanford University Press.

Agier, Michel. 2011. Managing the Undesirables: Refugee Camps and Humanitarian Government. Cambridge, UK: Polity.

al-Masri, Muzna. 2015. "Between Local Patronage Relationships and Securitization: The Conflict Context in the Bekaa Region." Lebanon Support, January.

al-Saadi, Yazan. 2015. "Restrictions, Perceptions, and Possibilities of Syrian refugees' Self-Agency in Lebanon." Lebanon Support, February 25.

Amnesty International. 2014. "Struggling to Survive: Refugee from Syria in Turkey." Available at: https:// www.amnestyusa.org/files/eur_440172014.pdf.

Auerbach, Adam. 2016. "Clients and Communities: The Political Economy of Party Network Organization and Development in India's Urban Slums." World Politics 68(1): 111-48.

Auyero, Javier. 2001. Poor People's Politics: Peronist Survival Networks and the Legacy of Evita. Durham, NC: Duke University Press.

Barnett, Michael. 2013. "Humanitarian Governance." Annual Review of Political Science 16(1): 379-98.
Bayat, Asef. 1997. Street Politics: Poor People's Movements in Iran. New York: Columbia University Press.

Beehner, Lionel. 2015. “Are Syria's Do-It-Yourself Refugees Outliers or Examples of a New Norm?” Journal of International Affairs 68(2): 157

Beirut Research and Innovation Center (BRIC). 2013. "Survey on the Livelihoods of Syrian Refugees in Lebanon." November. Available at https://www.oxfam. org/en/research/survey-livelihoods-syrian-refugeeslebanon.

Celikcan, Kadir. 2013 "Syrian Refugees Clash with Police in Turkish Camp." Reuters, March 27.

Clarke, Killian B. 2018. Data for: "When Do the Dispossessed Protest? Informal Leadership and Mobilization in Syrian Refugee Camps.” Data Project, QDR:10088. Syracuse, NY: Qualitative Data Repository [distributor]. https://doi.org/10.5064/F6CN723S.

Dancygier, Rafaela. 2010. Immigration and Conflict in Europe. Cambridge, UK: Cambridge University Press. 2017. Dilemmas of Inclusion: Muslims in European Politics. Princeton, NJ: Princeton University Press.

Dancygier, Rafaela, Karl-Oskar Lindgren, Sven Oskarsson, and Kåre Vernby. 2015. "Why Are Immigrants Underrepresented in Politics? Evidence from Sweden." American Political Science Review 109(4): 703-24

Dowty, Alan and Gil Loescher. 1996. "Refugee Flows as Grounds for International Action." International Security 21(1): 43-71.

Eisinger, Peter. 1973. "The Conditions of Protest Behavior in American Cities." American Political Science Review 67(1): 11-29.

Erdoğan, Murat. 2015. "Syrians in Turkey: Social Acceptance and Integration Research." HUGO. Available at: https://mmuraterdogan.files.wordpress.com/2014/12/ hugo-report-syrians-in-turkey-social-acceptance-andintegration-november-2014-04122014-en1.pdf.

Evans, Sara and Harry Boyte. 1986. Free Spaces: The Sources of Democratic Change in America. New York: Harper \& Row.

Falleti, Tulia and James Mahoney. 2015. "The Comparative Sequential Method." In Advances in ComparativeHistorical Analysis, eds. Kathleen Thelen and James Mahoney. Cambridge, UK: Cambridge University Press.

Feldman, Ilana. 2008. "Refusing Invisibility: Documentation and Memorialization in Palestinian Refugee Claims." Journal of Refugee Studies 21(4): 498-516.

- 2012. "The Humanitarian Condition: Palestinian Refugees and the Politics of Living." Humanity: An International Journal of Human Rights, Humanitarianism \& Development 3(2): 155-72.

Feldman, Ilana and Miriam Ticktin, eds. 2010. In the Name of Humanity: The Government of Threat and Care. Durham NC: Duke University Press Books.

Foucault, Michel. 1977. Discipline and Punish: The Birth of the Prison. New York: Vintage Books. 
Gay, Robert. 1994. Popular Organization and Democracy in Rio de Janeiro: A Tale of Two Favelas. Philadelphia, PA: Temple University Press.

Goldstone, Jack and Bert Useem. 1999. "Prison Riots as Microrevolutions: An Extension of State-Centered Theories of Revolution." American Journal of Sociology 104(4): 985-1029.

Goffman, Erving. 1961. Asylums: Essays on the Social Situation of Mental Patients and Other Inmates. New York: Doubleday.

Gould, Roger. 1993. "Collective Action and Network Structure." American Sociological Review 58(2): 182-96.

. 1995. Insurgent Identities: Class Community, and Protest in Paris from 1848 to the Commune. Chicago: University of Chicago Press.

Güçer, Mehmet, Sema Karaca, and O. Bahadır Dinçer. 2013. "The Struggle for Life between Borders: Syrian Refugees." USAK, May.

Holzer, Elizabeth. 2015. The Concerned Women of Buduburam: Refugee Activists and Humanitarian Dilemmas. Ithaca, NY: Cornell University Press

Horst, Cindy. 2006. Transnational Nomads: How Somalis Cope with Refugee Life in the Dadaab Camps of Kenya. New York: Berghahn.

Hyndman, Jennifer. 2000. Managing Displacement: Refugees and the Politics of Humanitarianism. Minneapolis: University of Minnesota Press.

International Crisis Group. 2013a. "Too Close for Comfort: Syrians in Lebanon.” Middle East Report 141, May 13. Brussels: International Crisis Group. 2013b. "Blurring the Borders: Syrian Spillover Risks for Turkey.” Europe Report 225, April 30. Brussels: International Crisis Group.

— 2014. "The Rising Cost of Turkey's Syrian Quagmire.” Europe Report 230, April 30. Brussels: International Crisis Group.

Jenkins, J. Craig. 1983. "Resource Mobilization Theory and the Study of Social Movements." Annual Review of Sociology 9:527-53.

Jha, Saumitra, Vijayendra Rao, and Michael Woolcock. 2007. "Governance in the Gullies: Democratic Responsiveness and Leadership in Delhi's Slums." World Development 35(2): 230-46.

Kirişci, Kemal. 2014. "Syrian Refugees and Turkey's Challenges: Going beyond Hospitality.” May. Washington, DC: Brookings Institution.

KIrmızıtaş, Hasan, 2013. “600 Suriyeli sınır dışı edildi!” Dogan Haber Ajansi, March 28.

Kitschelt, Herbert. 1986. "Political Opportunity Structures and Political Protest: Anti-Nuclear Activism in Four Democracies." British Journal of Political Science 16: 57-85.

Koopmans, Ruud, Paul Statham, Marco Giugni, and Florence Passy. 2005. Contested Citizenship: Immigration And Cultural Diversity in Europe. Minneapolis: University of Minnesota Press.
Lischer, Sarah. 2005. Dangerous Sanctuaries: Refugee Camps, Civil War, and the Dilemmas of Humanitarian Aid. Ithaca, NY: Cornell University Press.

Malkki, Lisa. 1995 Purity and Exile: Violence, Memory, and National Cosmology among Hutu Refugees in Tanzania. Chicago: Chicago University Press.

Marwell, Gerald and Pamela Oliver. 1993. The Critical Mass in Collective Action. Cambridge, UK: Cambridge University Press.

Marwell, Gerald, Pamela Oliver, and Ralph Prahl. 1988. "Social Networks and Collective Action: A Theory of the Critical Mass. III." American Journal of Sociology 94(3): 502-34.

McAdam, Doug. 1982. Political Process and the Development of Black Insurgency, 1930-1970. Chicago: University of Chicago Press.

McAdam, Doug, Sidney Tarrow, and Charles Tilly. 2001. Dynamics of Contention. Cambridge, UK: Cambridge University Press.

McCarthy, John and Mayer Zald. 1977. "Resource Mobilization and Social Movements: A Partial Theory." American Journal of Sociology 82(6): 1212-41.

McClurg, Scott. 2003. "Social Networks and Political Participation: The Role of Social Interaction in Explaining Political Participation.” Political Research Quarterly 56(4): 449-64.

Migdal, Joel. 1988. Strong States and Weak Societies: StateSociety Relations and State Capabilities in the Third World. Princeton, NJ: Princeton University Press.

Muggah, Robert. 2006. No Refuge: The Crisis of Refugee Militarization in Africa. London: Zed Books.

Netz, Reviel. 2010. Barbed Wire: An Ecology of Modernity. Middletown, CT: Wesleyan University Press.

Norwegian Refugee Council. 2013. "The Consequences of Limited Legal Status for Syrian Refugees in Lebanon.” Available at https://www.nrc.no/resources/ reports/the-consequences-of-limited-legal-status-forsyrian-refugees-in-lebanon/.

Olson, Mancur. 1965. The Logic of Collective Action. Cambridge, MA: Harvard University Press.

Onoma, Ato Kwamena. 2013. Anti-Refugee Violence and African Politics. Cambridge, UK: Cambridge University Press.

Özden, Şenay. 2013. "Syrian Refugees in Turkey." EUI Migration Policy Center, MPC Research Report 05. Available at http://www.migrationpolicycentre.eu/ docs/MPC-RR-2013-05.pdf

Paige, Jeffrey M. 1975. Agrarian Revolution: Social Movements and Export Agriculture in the Developing World. New York: Free Press.

Piven, Frances Fox and Richard Cloward. 1978. Poor People's Movements: Why They Succeed, How They Fail. New York: Vintage Books.

Polletta, Francesca. 1999. “'Free Spaces' in Collective Action." Theory and Society 28(1): 1-38. 
Popkin, Samuel. 1979. The Rational Peasant: The Political Economy of Rural Society in Vietnam. Berkeley: University of California Press.

Posen, Barry. 1996. "Military Responses to Refugee Disasters." International Security 21(1): 72-111.

Rawlence, Ben. 2016. City of Thorns: Nine Lives in the World's Largest Refugee Camp. New York: Random House.

REACH. 2014. "Al Za' atari Camp Population Profiling: Al Mafraq Governorate, Jordan.” April. Available at http://www.reach-initiative.org/al-zaatari-camp-population-profile-and-health-assessment-jordan.

—. 2015. "Za'atari Camp Population Count: Mafraq, Jordan.” February. Geneva: REACH.

Salehyan, Idean. 2008. "The Externalities of Civil Strife: Refugees as a Source of International Conflict." American Journal of Political Science 52(4): 787-801.

Salehyan, Idean and Kristian Gleditsch. 2006. "Refugees and the Spread of Civil War." International Organization 60(2): 335-66.

Scott, James. 1977. The Moral Economy of the Peasant: Rebellion and Subsistence in Southeast Asia. New Haven, CT: Yale University Press.

1998. Seeing Like a State: How Certain Schemes to Improve the Human Condition Have Failed. New Haven, CT: Yale University Press.

- 2009. The Art of Not Being Governed: An Anarchist History of Upland Southeast Asia. New Haven, CT: Yale University Press.

Search for Common Ground. 2014. "Dialogue and Local Response Mechanisms to Conflict between Host Communities and Syrian Refugees in Lebanon." May. Available at https://data2.unhcr.org/en/documents/ details/41354

Siegel, David. 2009. "Social Networks and Collective Action." American Journal of Political Science 53(1): 122-38.

Singerman, Diane. 1995. Avenues of Participation: Family, Politics, and Networks in Urban Quarters of Cairo. Princeton, NJ: Princeton University Press.

Skocpol, Theda. 1982. "What Makes Peasants Revolutionary?" Comparative Politics 14(3): 351-75.

Slater, Dan and Daniel Ziblatt. 2013. "The Enduring Indispensability of the Controlled Comparison." Comparative Political Studies 46(10): 1301-27.

Snow, David and Daniel Cress. 2000. "The Outcomes of Homeless Mobilization: The Influence of Organization, Disruption, Political Mediation, and Framing." American Journal of Sociology 105: 1063-104.

Stedman, Stephen and Fred Tanner, eds. 2003. Refugee Manipulation: War, Politics, and the Abuse of Human Suffering. Washington, DC: Brookings Institution.

Sullivan, Dennis and Sarah Tobin. 2014. "Security and Resilience Among Syrian Refugees in Jordan." Middle
East Report, October. Available at http://merip.org/ mero/mero101414

Tarrow, Sidney. 1998. Power in Movement: Social Movements and Contentious Politics. Cambridge, UK: Cambridge University Press.

Terry, Fiona. 2002. Condemned to Repeat?: The Paradox of Humanitarian Action. Ithaca, NY: Cornell University Press.

Thibos, Cameron. 2014. "One Million Syrians in Lebanon: A Milestone Quickly Passed.” Migration Policy Center, EUI. Available at: http://cadmus.eui.eu/handle/1814/31696.

Tilly, Charles. 1978. From Mobilization to Revolution. New York: McGraw-Hill.

UNHCR. 2013a. "Zaatari Governance Plan," June. Available at Clarke, Killian B. (2018) Data for "When Do the Dispossessed Protest? Informal Leadership and Mobilization in Syrian Refugee Camps." Data Project, QDR:10088. Syracuse, NY: Qualitative Data Repository [distributor]. https://doi.org/10.5064/F6CN723S . 2013b. "Participatory Needs Assessment: EJC

Refugee Camp," November 2013. Available at https:// data2.unhcr.org/en/documents/details/39315

2014. "Zaatari Refugee Camp: 2013 Safety and Security Report." March. Available at Clarke, Killian B. (2018) Data for "When Do the Dispossessed Protest? Informal Leadership and Mobilization in Syrian Refugee Camps.” Data Project, QDR:10088. Syracuse, NY: Qualitative Data Repository [distributor]. https://doi. org/10.5064/F6CN723S

. 2015a. "Safety and Security Report (2014)."

February 1. Available at Clarke, Killian B. (2018) Data for "When Do the Dispossessed Protest? Informal Leadership and Mobilization in Syrian Refugee Camps.” Data Project, QDR:10088. Syracuse, NY: Qualitative Data Repository [distributor]. //doi.org/ 10.5064/F6CN723S . 2015b. "Factsheet, Field Office-Irbid," MayJune. Available at //data2.unhcr.org/en/documents/ details/45242.

Useem, Bert and Jack Goldstone. 2002. "Forging Social Order and Its Breakdown: Riot and Reform in U.S. Prisons." American Sociological Review 67(4): 499-525. Vernby, Kåre. 2013. "Inclusion and Public Policy: Evidence from Sweden's Introduction of Noncitizen Suffrage." American Journal of Political Science 57(1): 15-29. Wolf, Eric. 1969. Peasant Wars of the Twentieth Century. New York: Harper and Row.

World Food Program. 2013. "Vulnerability Assessment of Syrian Refugees in Lebanon." Available at //reliefweb. int/report/lebanon/vulnerability-assessment-syrian-refugees-lebanon-2013-report. 